\title{
Ecocriticism and Shakespeare: The Gaia Hypothesis in As You Like It
}

\author{
Naglaa Abou-Agag \\ Associate Professor of English Literature, Department of English Language and Literature \\ Faculty of Arts, University of Alexandria, Egypt \\ n.abdelhameed@alexu.edu.eg
}

\begin{abstract}
This paper aims at examining William Shakespeare's As You Like It within the framework of Ecocriticism. It introduces Ecocriticism and defines two basic concepts related to it. These are Ecophobia and the Gaia Hypothesis. Different from interest in nature that has been seen in Romanticism, Pantheism and the Pastoral tradition; modern Ecocriticism is informed by scientific research and is political in orientation. Ecocriticism has become a valid perspective in the literary field and interdisciplinary education practices. It has also made its way into Shakespeare scholarship. The present paper investigates As You Like It within the framework of the Gaia Hypothesis which views Earth as a single organism capable of sustaining and rejuvenating itself through self-regulating mechanisms. Balance is created towards the end of the play when enough positive power associated with good, justice, comradeship, love, and solidarity is built up in the forest.
\end{abstract}

Keywords: Ecocriticism; As You Like It; Ecophobia; Gaia Hypothesis; Interdisciplinary Education.

\section{INTRODUCTION}

Sixteen years into the $21^{\text {st }}$ century, William Shakespeare, still speaks to us; still in many ways "our contemporary"; still provides ample scope for researchers coming to his texts, sonnets and plays alike, or to the performances of the plays armored with schools of literary criticism and performance theories. Postcolonialism, Feminism, Marxism, Cultural Criticism, New Historicism, and Psychoanalysis have provided insight into Shakespeare's oeuvre, bringing the bard closer to our life or explaining our contemporary times in light of his world. Similarly, Ecocriticism, flourishing over the past few decades, has created a new path for Shakespeare's critics. This paper attempts an ecocritical reading of As You Like It as an example of how Ecocriticism may highlight aspects of the literary text that would help us see our contemporary world from a more ecologically aware perspective. The relation between man and nature in As You Like Itis investigated within the framework of the Gaia Hypothesis which, though comes from science, may have bearing upon how nature is seen in literary texts.

We live in a world where issues of ecological awareness have been put forth for discussion in response to a number of important environmental issues. Climate change, the greenhouse effect, overpopulation, a global water crisis, nuclear energy, endangered species, and fossil fuels are part of the discourse of an ordinary $21^{\text {st }}$ century citizen. The scientific knowledge required for delving deep into the discussion of such topics may notbe a component of the education of such citizen. Yet, news bulletins and reports on television, newspaper articles, statements and studies coming out of international organizations, and speeches given by politicians have made environmental issues a major international concern upon which modern environmentalism is based. Questions about how man relates to nature and what man has done to nature are at the heart of Ecocriticism, drawing attention to the connections and networks found in nature and jeopardized due to man's intervention. Interconnectivity between man and nature is a view of the world similar to that of the Elizabethans and it suggestsembracing the Gaia Hypothesis, one of the main concepts in Ecocriticism, as a solution to the problems of the world of the 21 century. Visiting As You Like It to see the dialectics of nature and culture, and of animate and inanimate objects with a sense of presentism would provide 21 century readerswith a view of life where balance may be achieved. 


\section{LITERATURE REVIEW}

Ecocriticism has made its way into Shakespeare scholarship, investigating how characters throughout the drama of Shakespeare "speak of the world around them as though it is alive" (Egan, Green Shakespeare, 22), relate themselves to nature, or see in nature the reflection of their fears, struggles, and desires. This is explained in Joanna Rebecah Grossman's dissertation ShakespeareGrounded: Ecocritical Approaches to Shakespeare's Drama where she examines the representation of people as plants such as in Winter's Tale, the evolving of man to beast, to plant, and to dirt and ocean remains in Timon of Athens, the power of trees in The Tempest, the unnatural in Macbeth, and the use of animal imagery in As You Like It. Through her analysis of how plants, animals, rocks, and oceans are presented in a select number of Shakespeare's plays, Grossman shows Shakespeare's "skepticism of Elizabethan hierarchical orderings of creation" (37), putting the non-human at the forefront and showing that "it matters" (38). This powerful presence of natural elements in Shakespeare's oeuvres is perceived by Simon C. Estok as engendering fear and contempt and creating a sense of ecophobia, seen in the unpredictability of nature and in man being victimized by the weather for example as in King Lear (6). "The horror in Lear is one of displacement and disentitlement- specifically, displacement without an entourage into a world very far from home: the natural world" (Estok 23). Estok presents other examples of studying ecophobia including the analysis of race and gender in Othello and Pericles and the study of environment and social resistance in 2 Henry VI and 2 Henry IV. From the perspective of ecophobia nature is a hostile opponent man has been trying to control and to put into use.

\section{THEORETICAL FRAMEWORK}

In contrast to the fear and loathing, a sense of belonging to and harmony with nature may be seen in the Gaia Hypothesis which views the Earth as a single organism comprised of all life forms and all inorganic elements, previously considered background environment such as rocks, oceans, and atmosphere. Gaia is dynamic as it creates a geophysiological balance of energy and chemical elements, comparable to the physiological balance of an organism and it "might provide a basis for attempts to imagine the whole Earth in the literary and other media more usually addressed by ecocritics" (Garrard, Ecocriticism, 174-5). The term Gaia comes from James Lovelock's contention that the Earth's self-regulating system allows life to exist on the planet and it is this principle of selfregulation that decides whether or not life exists on other planets. According to Lovelock Gaia is "a complex entity involving the Earth's biosphere, atmosphere, oceans, and soil; the totality constituting a feedback of cybernetic system which seeks an optimal physical and chemical environment for life on this planet" (10). Along the same lines Tyler Volk explains that "biosphere [is] ...the integrated system of air, oceans, soil, and life" (29). Gabriel Egan revisits the Elizabethan worldview within the framework of Gaia and comes to the conclusion that the Gaia Hypothesis contributes to rehabilitating the Elizabethan notion of homogeneity and order and the belief in a structure that binds living matter (flora and fauna) and non-living matter (rocks, oceans, and the atmosphere) (Egan, "Shakespeare and Ecocriticism"). In the postmodern world where we live, the Gaia Hypothesis is a Transcendental idea and a means of sustaining "the awareness of our being anchored in the earth and the universe, the awareness that we are not here alone nor for ourselves alone, but that we are an integral part of higher, mysterious entities against whom it is not advisable to blaspheme" (Havel). This view is included in Martin Ogle's discussion of the value of the Gaia Hypothesis in the twenty first century and the role it may contribute towards spreading ecological and environmental awareness. Respect for mother Earth and celebration of the ability of nature to bring about balance and reconciliation link As You Like It to Ecocriticism in general and to the Gaia Hypothesis in particular.

Ecocriticism explores the ways in which the relations between human beings and the environment are presented in all kinds of cultural products with the aim of raising awareness of the power of nature on the one hand and of man's manipulation of it on the other. Ecocriticism is the methodology which investigates the "interconnectivity" between man and nature in literary works, along with the analysis of "conceptualizations of nature, $[\ldots]$ the function of its constructions and metaphorisations in literary and other cultural practices" (Gersdorf \& Mayer 10).It would focus on how nature is presented and how man treats nature. Enough evidence is there that man's progress and scientific advancement have had an immense impact upon nature. Man has always depended on natural resources for energy and food supplies and has changed natural habitats to create cities and build factories. In doing so, man has harmed the environment and disturbed the balance nature has always enjoyed. Awareness of 
environmental problems and of how nature is perceived and portrayed in cultural products is at the heart of Ecocritical practices. It is, in a broad sense, a form of "conservative political ambition: stop harming the ecosphere" (Egan, "Shakespeare and Ecocriticism"). Ecocriticism is, thus, made up of two components: ecology and literary criticism. While literary critics may not be well versed in ecological notions and theories, and "may not be qualified to contribute to debates about problems in ecology, [...] they must nevertheless transgress disciplinary boundaries and develop their own 'ecological literacy' as far as possible" (Garrard, Ecocriticism, 5). Hence, it is useful to integrate concepts coming from science and ecology into literary analysis with regard to the representation of nature.

Nature has been a core concept in literature as seen in the Elizabethan worldview, Romantic Pantheism, and American Transcendentalism. It is also at the heart of the Pastoral tradition. The Elizabethan conception of the world stressed the notion of "order", a strict system that governs all human experience and makes sense of the world, dividing it into the four kingdoms: mineral, vegetable, animal, and human, all linked to form the chain of being (Tillyard). The universe, the macrocosm, is mirrored in man, the microcosm, and the four humors: melancholy, phlegm, sanguis, and choler constitute man's temperament and the dominant humor decides man's character (Tillyard). Similarly, the relation between man and the world is presented according to Pantheism as a movement toward unity. All elements of nature, man included, compose an all-encompassing immanent god, a soul that pervades all matter. Most Romantic poets admired nature and saw it as the place where harmony, happiness, and spirituality may be achieved. This may be seen in William Wordswoth's "My Heart Leaps Up":

My heart leaps up when I behold

A rainbow in the sky:

So was it when my life began;

So is it now I am a man;

So be it when I shall grow old,

Or let me die!

The Child is father of the Man;

I could wish my days to be

Bound each to each by natural piety.

Man in the poem is part of a unified whole. Circularity is suggested in "[t]he Child is father of the Man" and continuity is created through the presence of the rainbow during all the phases of the speaker's life. The metaphor of the rainbow also suggests the circular shape and sustains the theme of unity created out of the connection and integration of constituent components. This theme is further emphasized in the days being tied together. In addition, "natural piety" reflects the spiritual power of nature and the bond the Romantics saw between man and nature.

Along the same lines, the connection between man and nature is viewed from the perspective of Transcendentalism, a literary, political, religious, and philosophical movement in the early nineteenth century in the United States, seen in the poetry of Ralph Waldo Emerson and Henry David Thoreau among others. Transcendentalists emphasized unity rather than the Trinity of God and urged each human being to find a personal relation to the universe. An analysis of major works by the Romantics and the Transcendentalists is rendered in Ashton Nichols's Beyond Romantic Ecocriticism: Toward Urbanatural Roosting where he moves beyond the split between nature and culture "towards the more inclusive idea of 'urbanatural roosting'" (xvii). Roosting is a "new way of living more self-consciously on the earth" (3) where "everything can be imagined as part of a single global ecosystem" (184). This also reiterates the sentiment in Pastoral poetry which describes the lives of shepherds and shepherdesses and celebrates the simplicity and happiness of it, stressing the view that out there in nature man may enjoy a kind of idyllic existence. The notion of interconnectivity and the view of man as an intrinsic part of nature are reiterated in the modern and contemporary times through Ecocriticism. 
Emerging in the 1990s with the founding of the ASLE (Association for the Study of Literature and Environment), the launching of the journal ISLE (Interdisciplinary Studies inLiterature and Environment), and the publication of The Ecocriticism Reader (1996) edited by Cheryll Glotfelty and Harold Fromm, Ecocriticism, being interdisciplinary in nature, was mainly concerned with how human beings relate to the environment, with the intention of showing the interconnectedness of all things. It then gained momentum at the turn of the twenty first century with the publication of Greg Garrard'sEcocriticism (2004) where he reaches the conclusion that "it is essential for ecocritics to give greater consideration than they have thus far to the transformation in the dominant meaning of the word 'earth': from the most immediate ground of existence, the soil, to life's largest context, the biosphere" (162).

This view that earth is the biosphere has made its way into education and literary criticism through a strategy stressing interdisciplinarity. One of the most fascinating interdisciplinary links to be made is the true place of human society in the Gaian system. Within this system, man's activities in creating cultures and civilizations may be seen as "marvelous, biological adaptations of human beings that enmesh with the rest of life" (Ogle). With this viewpoint, humanity can rise to the challenge of adapting culturally to allow human beings to live in harmony with the rest of nature (Ogle). This may be achieved through approaching the study of literature in a manner that would encourage students to think about nature and how they relate to it. The experiment described by Garrard comprises three phases. The first is "Infoshpere" where students see how places in nature are represented in the media. The second phase is "Biosphere" where students spend some time out of doors away from human habitation, and the third is"Ecopeotry" where students are exposed to poems about nature (Garrard, "Ecocriticism"). Raising ecocritical awareness has also taken the form of a social and an entertainment activity, The Eden Project in Cornwall UK, designed to connect human beings with each other and with the living world, exploring how humanity can work towards a better future. The Eden Project is made up of massive Biomes housing the largest rainforest in captivity. Stunning plants, exhibitions and stories serve as a backdrop to striking contemporary gardens, summer concerts and exciting year-round family events (https://www.edenproject.com/eden-story).In his book Ecocriticism, Garrard describes The Eden Project as resembling Biosphere, "an experiment in imaginary human ecology that flirts with utopianism, but ultimately epitomizes something like global georgic" (182).The Eden Project is an attempt at recreating wildlife for the inhabitants of modern cities, living in blocks of flats, working in factories, and using up natural resources. The abovementioned experiment in teaching poetry and The Eden Project are both examples of Ecocritical practices. The philosophy behind both may also manifest itself in the form of revisiting literary texts with the intention of describing how they view the relation between man and nature.

\section{DiSCUSSION AND ANALYSIS}

As You Like It lends itself to the ecocritical approach, as has already been noted by critics, in that it is set mostly in the forest, acting as "both a celebration and a critique of the pastoral" (Roy 57). The characters wander in the forest, comparing themselves to animals and birds and describing their actions in terms of "hunting" and "flying" or they settle in the forest, like the banished Duke and his men, and therefore may be seen as "part of the wildlife" (Grossman 219). The play's introduction of the topic of vegetarianism, though at the time was not seen as a positive stance (Estok, "Green"), its dramatization of Jaques' sympathy for the wounded deer and his anger about marring the trees with the love songs (Pal 6), and the association between Jaques and melancholy within the Elizabethan understanding of the humors (Brown 4 \& 12) connect the play to the animal rights movement, to the save the planet campaigns, and, I would argue, to the recently formulated Gaia Hypothesis.

In her investigation of Jaques' disposition, Angela Elizabeth Brown sees his melancholy as being "ingrained into his very nature", the result of "an excess of black bile"(12), which causes sadness and tears according to the Elizabethan imagination. Brown's analysis of "Monsignor Melancholy" (III, ii, 290) with his wit, "sullen fits" (II, i, 67), "sundry contemplation" (IV, I, 16), sadness at the fate of animals killed to provide food for man, and his desire to "cleanse the foul body of th'infected world" (II, vii, 60) sustains her view that through the character of Jaques, Shakespeare "challenges readers to reexamine their relationship with nature and also with each other and urges them to make adjustments to their lives accordingly" (26). Jaques' character introduces an ecocentric twist in the play through his "compassion to the wounded deer" (Kumaresan \& Boopathi), seen as "the native denizens of the land onto which Duke Senior and his men have trespassed" (Grossman 44).Within this view, Jaques in As You Like It criticizes man's intrusion upon nature in whatever form it may take. 
The description of nature in As You Like It links the play to the Pastoral tradition. The beauty, serenity, and purity of the environment in the forest make it anappropriate milieu for the flourishing of love, one prominent theme in the play. The path to this idyllic setting is marked, according to Grossman, by reference to birds as in the verb "flock" (202). It is truethat the cruelty to animals, the doubt thrown upon the longevity of love, and the discussion of greed and violence in As You Like Itmay deconstruct the view that in nature man leads a perfect life enjoying happiness and harmony with his surroundings; the picture of life propagated by the Pastoral tradition. However, the healing power of the forest brings about balance and restores order in the palace with Duke Senior reinstated as King at the end of the play. The forest in this case is a retreat for the characters seeking asylum away from injustice and persecution in the world of the palace. The forest is a place where they, as Celia puts it, "go in content/To liberty and not to banishment" (I, iii, 134-5) in spite of Rosalind's fear that they may be in danger if they travel that far, being young and beautiful. Their plan is to go in disguise: Rosalind as a young man and Celia as a poor country girl. The journey into the forest provides them with the chance to develop happy love stories and eventually to marry their lovers and everything ends for them on a happy note.

The interconnection between humans and nature in As You Like It is revealed through the use of imagery. Images of animals, birds, and plants are used extensively to refer to human beings and music and singing permeate the atmosphere of the play. Duke Senior refers to Jaques as being "transform'd into a beast" (II, vii, 1), Orlando describes himself as being like "a doe" going to find his "fawn" to give him food (II, vii, 28), and Celia speaks of her relationship with Rosalind as similar to that of "Juno's swans" (I, iii, 72). Other examples include to reference to "fat sheep' (III, ii, 27), "the ewes and the rams"" (III, ii, 77), "the ox", "the horse", "the falcon", "the pigeons" (III, iii, 72-3), and the "green and gilded snake" about to attack a sleeping man under a tree but upon seeing Orlando, "it unlink'd itself,/ And with indented glides did slip away" (IV, iii, 108-112). These images affirm the interconnectedness between human and non-human creatures seen and propagated by Ecocriticism. This bond is further emphasized in Rosalind's words describing how she and Celia relate to the forest as "the cony that you see dwell where she is/ kindled" (III, ii, 327-8).However, the forest may also be dangerous as in the description of the lioness about to attack Oliver, "with udders all drawn dry,/ Lay couching, head on ground, with catlike watch" (IV, iii, 114-5). The image of harmony and peacefulness in Rosalind's words stands in opposition to the image of peril and death in Oliver's account. It seems that Oliver's intentions are detected by nature and therefore he cannot enjoy safety in the forest, whereas Celia and Rosalind go into the forest seeking asylum away from the injustices of the courtly world and brining no harm to nature. They manage to settle in and their house is presented in terms of nature imagery, "[a] sheepcote fenc'd about with olive-trees" (IV, iii, 76). The idyllic existence suggested in this image of the house finds expression in the sound imagery in the music and the songs which fill the play. Duke Senior asks for "some music" and requests Amiens to "sing" (II, vii, 173). The same image is suggested in Touchstone's desire to "rime" (III, ii, 94), in Celia's wish to "sing" her song without interruption (III, ii, 242-3), and in reference to the "sweet bird's throat" in Amiens's song (II, v, 4). The sweetness of the love poems Orlando writes and hangs up the trees contributes to the magic atmosphere of the forest and emphasizes the bond between man and nature as is seen in Orlando's statement that the "trees shall be...[his] books" where he will post his thoughts and give expression to his feelings (III, ii, 5).

Therefore, the forest in As You Like It, in spite of Jaques' melancholy, the rough winter weather (II, ii, $26 \& 7$ ) and the existence of dangerous animals, is in general a happy place, with positive vibes outweighing negative ones, reaching a more balanced form of existence where love prevails and the abdicated Kingreceives news that he is reinstated. The characters in the forest belong to two categories: the country people such as Corin, Silvius, William, and Audrey and the people fleeing the palace, the man-made structure seeking asylum in the forest. First Duke Senior seeks refuge in the forest after his brother, Duke Frederick, usurps his throne. Duke Senior is accompanied by a group of loyal Lords attending upon him. The other characters who run into the forest include Orlando, Rosalind and Celia and towards the end of the play Oliver and Duke Frederick venture into the forest for specific purposes. Orlando, unfit for the courtly world, being "trained...like a peasant" (I, I, 54-5), is incapable of standing up to his brother, Oliver, who is planning to "[b]urn the lodging where" (II,iii, 23) he sleeps. Celia is ordered by Duke Frederick to leave the Palace without explaining to her what she has done wrong. In response to her question, he tells her "Thou art thy father's daughter; there's/enough" (I, iii. 54-5). Celia comes to the forest out of her own choice because she loves 
Rosalind and hates to see her leave. The three characters thus flee a world of conspiracies and injustices, already burdened with the curse of violating the Elizabethan worldview in deposing a King. Deposing or killing a king results in chaos, civil war, and death as in Macbeth, Hamlet, Julius Caesar and Richard III as examples of many of Shakespeare's plays.

In As You Like It deposed Duke Senior is not killed and no civil war ensues after his banishment. He moves to the forest which stands in direct contrast to the corruption of the courtly world. Duke Senior's words describing his life in the forest are evidence enough:

"And this our life exempt from public haunt,

Finds tongues in trees, books in the running brooks,

Sermons in stones, and good in everything" (II, i, 15-17).

The Gaian principle of the unity between all components of life on Earth is apparent in Duke Senior's words. Away from the restrictions of the courtly world and the complications of the realm of politics, Duke Senior lives in peace and the four love stories described in the play flourish with the four couples: Orlando and Rosalind, Celia and Oliver, Silvius and Phoebe, and Touchstone and Audrey get married at the end. The festivity at the end of the play re-emphasizes the sense of harmony suggested in Duke Senior's commentary on life in the forest. Similar to the effect Gaia has regarding maintaining order and balance, love in As You Like It is a healing power; a force bringing happiness into people's lives. The forest is also anourishing place, where people are fed literally as in Duke Senior's invitation to Orlando to "Sit down and feed, and welcome to our table" (II, vii, 105)and in Amiens's intention to seek the Duke because "his banquet is /prepared" (II, v, 60-1). On the spiritual level, in the forest "The sight of lovers feedeth those in love" (III, iv, 53).Food imagery in As You Like It is significant as it raises the issue of sustenance and survival.

Movement from the realm of the courtly world to the forest in As You Like Itraises the issue of the antithesis between nature and culture which is an important concern within the framework of the Gaia Hypothesis. In the context of writing and putting the play on stage during the Elizabethan times, although metropolitan London was attracting people from rural areas with the work opportunities it offered part of "urbanity itself was a powerful counter-current in imaginative identification" (MacLean et al. 5). This was translated into the habit of having a house in the country, away from the filth and the diseases in the city (5). Therefore the pastoral retreat from city life was key motif in Renaissance poetry (Garrard, Ecocriticism, 33). In As You Like It, the forest becomes the dwelling place of those who have problems in the courtly world and are looking for respite away from the evils of the palace and the circles around it. The forest provides them with a safe haven where regeneration and self-regulation are possible as they are in a context similar to Daisyworld. The model of the Daisyworld created by Andrew J. Watson and James Lovelock "is a cloudless planet with a negligible atmospheric greenhouse on which the only plants are two species of daisy of different colours. One species is dark - ground covered by it reflects less light then bare ground - while the other is light and reflects more than the bare ground" (284). T. Lenton further describes this model as follows:

Daisyworld is an imaginary gray world orbiting a star like our Sun that gets more luminous with time. The world is seeded with two types of life, black and white daisies. These share the same optimum temperature for growth of $22.51 \mathrm{C}$ and limits to growth of $51 \mathrm{C}$ and $401 \mathrm{C}$. When the temperature reaches $51 \mathrm{C}$, the first seeds germinate. The paleness of the white daisies makes them cooler than their surroundings, hindering their growth. The black daisies, in contrast, warm their surroundings, enhancing their growth and reproduction. As they spread, the black daisies warm the planet. This further amplifies their growth and they soon fill the world. At this point, the average temperature has risen close to the optimum for daisy growth. As the Sun warms, the temperature rises to the point where white daisies begin to appear in the daisy community. As it warms further, the white daisies gain the selective advantage over the black daisies and gradually take over. (817)

The balance between white daisies and black daisies is reflected in the balance created in the play when enough positive power associated with good, justice, comradeship, love, and solidarity is built up in the forest. The realm of the courtly world, where negative vibes reside, becomes weaker with only Oliver and Duke Frederick remaining there. They cross the border between palace and forest with the intention of killing Orlando and Duke Senior respectively. However, both are affected by the 
milieu of the forest and are changed because of their exposure to its positive vibes. The forest then becomes a milieu where people become better as Oliver admits:

"'Twas I; but 'tis not I. I do not shame

To tell you what I was, since my conversion

So sweetly tastes, being the thing I am". (IV, iii, 135-7)

This change comes after Orlando rescues Oliver from the lioness that was about to attack him. Finally, the forest is a condition that contributes to the restoration of order and balance as seen in Duke Senior's restoration of his throne. Duke Frederick, who comes to the forest with the intention of killing Duke Senior, meets with a religious man and:

After some question with him, was converted

Both from his enterprise and from the world;

His crown bequeathing to his banish'd brother,

And all their lands restor'd to them again

That were with him exil'd. (V, iv, 157-161)

Along with the restoration of Duke Senior's throne comes there affirmation of the Elizabethan worldview with the King at the top of the political structure. The forest environment has a major effect upon the characters. Through relations with the world of nature, man becomes more in contact with what matters most in life. Love and justice emerge triumphant at the end of the play. The interconnectivity between man and nature which provides scope for reconciliation and regeneration replicates the self-regulation law upon which the Gaia Hypothesis is established. The characters that move away from the courtly world to the realm of nature go through self-cleansing processes that stave off negative energy and evil powers and strengthen positive energy represented in love and justice.

\section{CONCLUSION}

The world presented at the end of As You Like Itis better than the world described at the beginning of the play. The atmosphere of conspiracies, insecurities, and grievances dominating the early part of the play is subsumed gradually as characters run away from the restraints and complications of the courtly world into the forest; a free magical environment where they become reconnected with the biosphere. It could be argued that the forest in As You Like It functions in the same way The Eden project works in our contemporary times. It offers human beings the chance to reconnect with nature; it enlightens and enriches their souls. Similarly, As You Like It strongly affirms the view that there is no hierarchical dualism between nature and culture. Instead both are interconnected and interrelated. The beauty of the forest in As You Like It and its spiritual and healing power bring about change in people and in social and political structures.

\section{ACKNOWLEDGMENTS}

This paper is based on a presentation under the same title given at the Academic Conference on Shakespeare 400 held by The Bibliotheca Alexandrina, Egypt, April 23-25, 2016.

\section{REFERENCES}

[1] Egan, Gabriel. Green Shakespeare: From Ecopolitics to Ecocriticism. London: Routledge, 2006.

[2] Grossman, Joanna Rebecah. Shakespeare Grounded: Ecocritical Approaches to Shakespearean Drama. Doctoral Dissertation. Harvard University, 2014. February 16, 2016. Web.

[3] Estok, Simon C. Ecocriticism and Shakespeare: Reading Ecophobia. New York: Palgrave Macmillan: digital printing, 2012. February 16, 2016. Web.

[4] Garrard, Greg. Ecocriticism. London: Routledge, 2004.

[5] Lovelock, James. Gaia: A New Look at Life on Earth. Oxford: Oxford University Press, 2000.

[6] Volk, Tyler. "How the Biosphere Works". Gaia in Turmoil: Climate Change, Biodepletion, and Earth Ethics. Eileen Crist \& H. Bruce Rinker (eds.). Cambridge: The MIT Press, 2010. 27-40. 
[7] Egan, Gabriel. "Shakespeare and Ecocriticism: The Unexpected Return of the Elizabethan World Picture". Literature Encompass, vol. 1. 2004. February 29, 2016. Web.

[8] Havel, Vaclav. "The Need for Transcendence in the Postmodern World". 1994. April 29, 2016. Web.

[9] Ogle, Martin. "Gaia Theory: Model and Metaphor for the $21^{\text {st }}$ Century". March 11, 2016. Web.

[10] Gersdorf, Catrin \& Sylvia Mayer. "Nature in Literary and Cultural Studies: Defining the Subject of Ecocriticism- an Introduction". Catrin Gersdorf \& Sylvia Mayer (eds.). Nature and Cultural Studies: Transatlantic Conversations on Ecocriticism. Amsterdam: Rodopi, 2006. 9-24.

[11] Tillyard, E.M.M. The Elizabethan World Picture. 1942. February 29, 2016. Web.

[12] Wordsworth, William. "My Heart Leaps Up". April 12, 2016. Web.

[13] Nichols, Ashton. Beyond Romantic Ecocriticism: Toward Urbanatural Roosting. New York: Palgrave Macmillan: 2011.

[14] Glotfelty, Cheryll \& Harold Fromm (eds.). The Ecocriticism Reader: Landmarks in Literary Ecology. Athens \& London: The University of Georgia Press, 1996.

[15] Garrad, Greg. "Ecocriticism: The Ability to Investigate Cultural Artefacts from an Ecological Perspective". February 29, 2016. Web.

[16] Roy, Animesh. "Ecocriticism and Shakespeare: Ecocritical Dialectics in William Shakespeare's As You Like It". MIT International Journal of English Language and Literature. Vol. 2, No. 2, August 2015. February 29, 2016. Web.

[17] Pal, Dipanwita. "Forest of Arden Revisited: A Study of Shakespeare's As You Like It from an Ecocritical Perspective". Lapis Lazuli: An International Literary Journal (LLILJ). Vol.2, No. 2, Autumn 2012. March 11, 2016. Web.

[18] Brown, A. E. Earthbound Humors: An Ecocritical Approach to Melancholy on As You Like It and Hamlet. MA Thesis. University of New Orleans: 2010.February 29, 2016. Web.

[19] Shakespeare, William. As You Like It. Oxford: The Clarendon Press, reprinted 1980.

[20] Kumaresan, R. \& S. Boopathi. "Eco-Consciousness in Shakespeare's As You Like It". Journal of Humanities and Social Science (IOSR-JHSS). 33-34. February 29, 2016. Web.

[21] MacLean, Gerald \& Donna Landry \&Joseph P. Ward. "Introduction: The Country and the City Revisited, C. 1550-1850". Geral MacLean \& Donna Landry \&Joseph P. Ward (eds.). The Country and the City Revisited. Cambridge: Cambridge University Press, 1999. 1-23.

[22] Watson, Andrew J. \& James E. Lovelock. "Biological Homeostasis of the Global Environment: The Parable of Daisyworld". Tellus, 35B, 1983. 284-289.March 11, 2016. Web.

[23] Lenton, T. "Gaia Hypothesis". Elsevier Science Ltd. 2003. 815-820. April 12, 2016. Web.

\section{AUTHOR'S BIOGRAPHY}

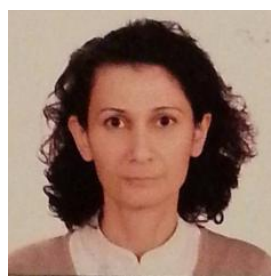

Dr. Naglaa Abou-Agag, is an Associate Professor in the Department of English Language and Literature, Faculty of Arts, University of Alexandria, Egypt. She has teaching experience at the University of Alexandria and Beirut Arab University (Lebanon).

Her research interests cover Literary Theory, Postcolonial Literature, Comparative and Cultural Studies, and Modern Drama. She has participated in a number of local and international conferences and has also done translation from and into English. 